21. Karhunen L, Franssila-Kallunki A, Rissanen A, et al. Determinants of resting energy expenditure in obese nondiabetic Caucasian women. Int J Obes Relat Metab Disord 1997;21:197-202.

22. Berlinger WG, Potter JF. Low body mass index in demented outpatients. J Am Geriatr Soc 1991;39:973-978.

23. Braak E, Griffing K, Arai K, et al. Neuropathology of Alzheimer's disease: what is new since A. Alzheimer? Eur Arch Psychiatry Clin Neurosci 1999;249(suppl 3):III-14III-22.

24. Bacon AW, Bondi MW, Salmon DP, et al. Very early changes in olfactory function due to Alzheimer's disease and the role of apolipoprotein E in olfaction. Ann NY Acad Sci 1998;855:723-731.
25. Borenstein Graves A, Bowen JD, Rajaram L, et al. Impaired olfaction as a marker for cognitive decline. Interaction with apolipoprotein E $\varepsilon 4$ status. Neurology 1999;53: $1480-1487$.

26. Grundman M, Corey-Bloom J, Jernigan T, et al. Low bodyweight in Alzheimer's disease is associated with mesial temporal cortex atrophy. Neurology 1996;46:1585-1591.

27. Soininen H, Partanen K, Pitkänen et al. Decreased hippocampal volume asymmetry on MRIs in nondemented elderly subjects carrying the apolipoprotein E $\varepsilon 4$ allele. Neurology 1995;445:391-392.

28. Geroldi C, Pihlajamäki M, Laakso MP, et al. APOE- $\varepsilon 4$ is associated with less frontal and more medial temporal lobe atrophy in AD. Neurology 1999;53:1825-1832.

\title{
Neuro/mages
}
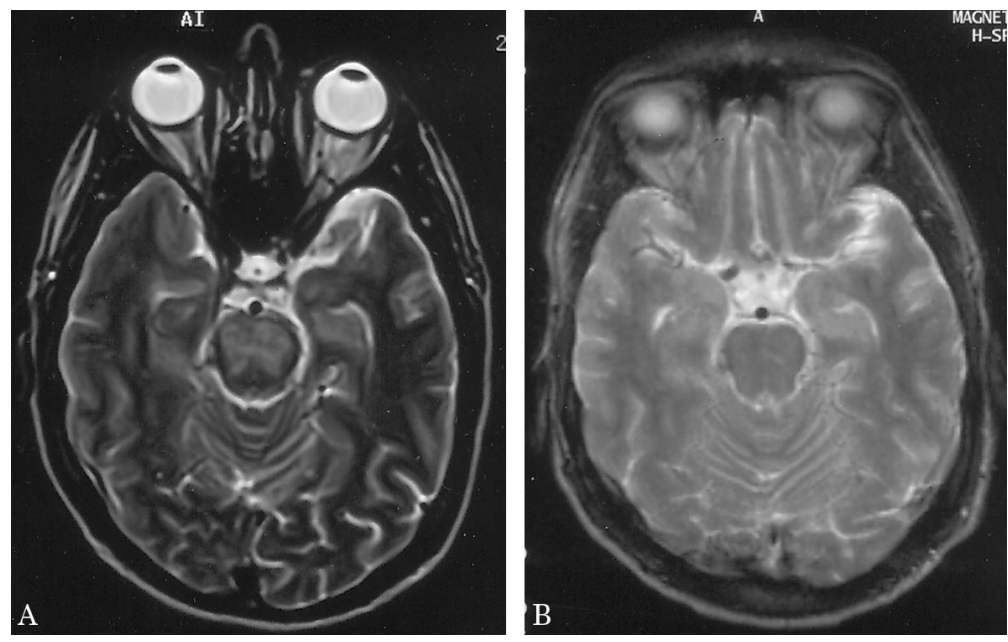

Figure. (A) T2-weighted image (repetition time 4000 , echo time 95) shows pontine edema. (B) T2-weighted image 2 weeks later (repetition time 3657, echo time 96) shows almost complete resolution of the abnormal findings.

\section{Reversible pontine edema in hypertension}

Cornelia Drees, MD, Luay Alkotob, MD, Philip M. Hall, MD, Derk Krieger, $\mathrm{MD}$, Cleveland, $\mathrm{OH}$

A 28-year-old right-handed man presented with blurry vision and diplopia. He had a blood pressure of 242/182 mm $\mathrm{Hg}$, papilledema, and bilateral VIth nerve palsies. Laboratory values indicated acute renal failure. MRI of the brain showed selective pontine edema (figure, A). A repeat MRI showed almost complete resolution (figure, B).
We suspect that this is a case of reversible posterior leukencephalopathy. ${ }^{1}$ However, the outstanding feature is the isolated involvement of the pons, which is probably due to less abundant sympathetic innervation in parts of the posterior circulation making it more susceptible to vasogenic edema. ${ }^{2}$

1. Hinchey J, Chaves C, Appignani B, et al. A reversible posterior leukoencephalopathy syndrome. N Engl J Med 1996;334:494-500.

2. Beausang-Linder M, Bill A. Cerebral circulation in acute arterial hypertension-protective effects of sympathetic nervous activity. Acta Physiol Scand 1981;111:193-199. 


\section{Neurology}

Reversible pontine edema in hypertension

Cornelia Drees, Luay Alkotob, Philip M. Hall, et al.

Neurology 2001;56;659

DOI 10.1212/WNL.56.5.659

\section{This information is current as of March 13, 2001}

\section{Updated Information \&} Services

References

Permissions \& Licensing

Reprints including high resolution figures, can be found at: http://n.neurology.org/content/56/5/659.full

This article cites 2 articles, 0 of which you can access for free at: http://n.neurology.org/content/56/5/659.full\#ref-list-1

Information about reproducing this article in parts (figures,tables) or in its entirety can be found online at:

http://www.neurology.org/about/about_the_journal\#permissions

Information about ordering reprints can be found online: http://n.neurology.org/subscribers/advertise

Neurology ${ }^{\circledR}$ is the official journal of the American Academy of Neurology. Published continuously since 1951, it is now a weekly with 48 issues per year. Copyright . All rights reserved. Print ISSN: 0028-3878. Online ISSN: 1526-632X.

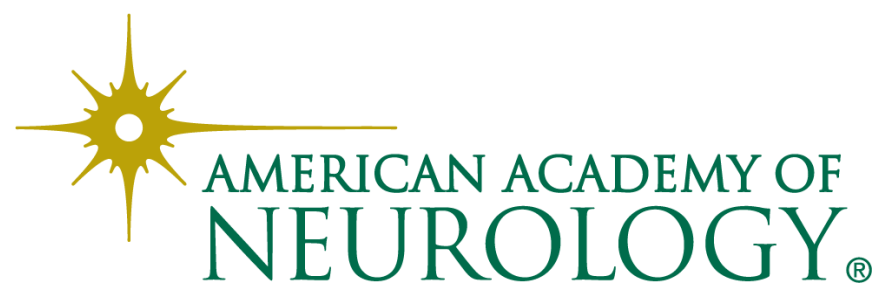

